\title{
Psychometric properties of the Impulsive/Premeditated Aggression Scale in Portuguese community and forensic samples
}

\author{
Propriedades psicométricas da versão portuguesa da Escala de Agressão \\ Impulsiva e Premeditada em amostras comunitárias e forenses
}

Ana Rita Cruz, ${ }^{1}$ (D) Rita Pasion, ${ }^{1}$ Andreia Castro Rodrigues, ${ }^{2,3}$ Carmen Zabala, ${ }^{4}$ Jorge Ricarte, ${ }^{5}$ Fernando Barbosa ${ }^{1}$

\begin{abstract}
Introduction: Aggression can be defined according to impulsive or premeditated features. Impulsivity is defined as an uncontrolled and unplanned form of aggression. On the contrary, premeditation requires planning and is goal-oriented.

Objective: The purpose of this study was to validate the basic psychometric properties of the Impulsive/Premeditated Aggression Scale (IPAS) into European Portuguese. The scale evaluates aggression according to impulsive and premeditated features, which are considered the predominant forms of aggressive behavior, and can be used in community, forensic and clinical settings.

Methods: Participants from a community sample $(n=957 ; 424$ male) and incarcerated individuals ( $n=115$, all male) completed the IPAS.

Results: Internal consistency and reliability indicated that the scale has good psychometric properties in both samples. Data from a principal component analysis (PCA) demonstrated similarities to previous structures reported in the literature.

Conclusions: The scale demonstrated to be sensitive to the bimodal classification of aggression in community and forensic samples, indicating its utility in the characterization of aggressive patterns.
\end{abstract}

Keywords: IPAS, psychometric properties, impulsive aggression, premeditated aggression, aggressive patterns.

\section{Resumo}

Introdução: A agressão pode ser definida de acordo com as características de impulsividade ou premeditação. A impulsividade é definida como uma forma descontrolada e não planeada de agressão. Pelo contrário, a premeditação requer planejamento e orienta-se para um objetivo.

Objetivos: $O$ objetivo deste estudo foi validar as propriedades psicométricas básicas da Escala de Agressão Impulsiva e Premeditada (Impulsive/Premeditated Aggression Scale IPAS) para o português europeu. A escala avalia a agressão de acordo com características impulsivas e premeditadas, que são consideradas as formas predominantes do comportamento agressivo, e pode ser usada em contextos comunitário, forense e clínico.

Métodos: A escala foi aplicada a participantes de uma amostra comunitária ( $n=957 ; 424$ homens) e reclusos ( $n=115$, todos homens).

Resultados: A consistência interna e a confiabilidade indicaram que a escala possui boas propriedades psicométricas para as duas amostras. Os dados da análise de componentes principais (principal component analysis - PCA) demonstraram semelhanças com estruturas fatoriais previamente reportadas na literatura. Conclusão: A escala revelou ser sensível à classificação bimodal da agressão em amostras comunitárias e forenses, indicando sua utilidade na caracterização de padrões agressivos.

Descritores: IPAS, propriedades psicométricas, agressão impulsiva, agressão premeditada, padrão de agressividade.

\footnotetext{
${ }^{1}$ Laboratório de Neuropsicofisiologia, Universidade do Porto, Porto, Portugal. ${ }^{2}$ Centro de Investigação em Psicologia (CIPsi), Escola de Psicologia, Universidade do Minho, Braga, Portugal. ${ }^{3}$ Faculdade de Direito, Universidade Lusíada - Norte (Porto), Porto, Portugal. ${ }^{4}$ Facultad de Terapia Ocupacional, Logopedia y Enfermería, Universidad de Castilla-La Mancha, Toledo, Espanha. ${ }^{5}$ Departamento de Psicología, Universidad de Castilla-La Mancha, Albacete, Espanha. Submitted Jun 26 2018, accepted for publication Oct 012018.

Suggested citation: Cruz AR, Pasion R, Castro Rodrigues A, Zabala C, Ricarte J, Barbosa F. Psychometric properties of the Impulsive/Premeditated Aggression Scale in Portuguese community and forensic samples. Trends Psychiatry Psychother. 2019;41(2):144-148. http://dx.doi.org/10.1590/2237-6089-2018-0055
} 


\section{Introduction}

Aggression is a multifaceted construct that could be behaviorally expressed in a myriad of ways. ${ }^{1,2}$ There is a wide range of aggressive behaviors within a continuum between its verbal forms, such as insulting another person, to most extreme and violent manifestations, such as rape or murder. ${ }^{1,3}$ Those acts represent a major cost in society, from both clinical and forensic perspectives, and a better understanding could contribute to increase the efficacy of risk prevention programs.

Despite the heterogeneity of aggressive behaviors, they may be primarily classified as impulsive or premeditated. ${ }^{2-4}$ Impulsivity can be characterized as a predisposition for rapid and unplanned reactions towards internal or external stimuli, disregarding the potential risk and consequences for the self or the others. ${ }^{5}$ Impulsive aggressive outbursts are emotionally charged, highly spontaneous, uncontrolled, unpredictable, occur in response to a perceived threat or danger ${ }^{6-9}$ and may not be proportional to the trigger event. ${ }^{3,6}$ Impulsive aggression is also known as reactive, affective, emotional, expressive or nonplanned. ${ }^{9}$ On the contrary, premeditated aggression requires planning and forethought, being intentionally executed.6,10,11 Premeditated aggression tends to be oriented towards a goal, such as obtaining money, restoring one's self-image, securing power and dominance over others, or controlling criminal activities. ${ }^{12}$ Premeditated aggression is also mentioned in the literature as instrumental, proactive, predatory and cold-blooded. 9,13,14

In order to assess these two types of aggression, Stanford et al. ${ }^{3}$ developed the Impulsive/Premeditated Aggression Scale (IPAS), which equally assesses the two aggressive patterns. The IPAS has been translated into Chinese, ${ }^{15}$ Portuguese, ${ }^{16,17}$ Spanish $^{18}$ and Dutch. ${ }^{19}$ Research testing the factorial structure of the scale ${ }^{4,18-}$ 20 identified the expected main factors impulsive aggression (IA) and premeditated aggression (PM) and no significant differences in the distribution of the items across dimensions (Table 1 ). Overall, in previous research, the scale demonstrated good psychometric properties across community, ${ }^{20-22}$ forensic ${ }^{4,23-25}$ and clinical samples. ${ }^{18,26,27}$

Therefore, following previous research, the aim of this study was to evaluate psychometric properties of the IPAS, namely internal consistency and reliability, in both forensic and community Portuguese samples, and to test the factorial structure of this scale.

\section{Method}

\section{Participants}

The scale was administered to a community sample of 957 participants (424 male) with a mean (M) age of 28.9 years (standard deviation $[S D]=12.9$ ), and 115 male inmates $(M=38.0$ years, $S D=9.68)$ from three prisons located in the northern region of Portugal. All participants provided informed consent and no compensation was given for their collaboration in this study.

\section{Material and procedure}

The IPAS is a self-report, self-administered scale that assesses impulsiveness vs. premeditation of aggressive behavior. It comprises 30 items rated on a 5-point Likert scale (1 - strongly disagree to 5 - strongly agree) and measures aspects of planning and control during aggressive acts. The scale can be scored either dimensionally or categorically (Stanford MS, Classification procedures, unpublished manual, and Stanford et al. $^{3}$ ). When dimensionally analyzing the individual level of impulsiveness or premeditation, all items are summed to obtain an IA and PM score. Discrete categories (impulsive vs. premeditated) are obtained by a categorical approach in which only the percentage of positive items ( 5 - strongly agree or 4 agree) for each aggression scale is calculated (Stanford MS, Classification procedures, unpublished manual). Therefore, not all participants may be accounted for in a categorical scoring, but rather only those scoring 4 or 5 in the items of each subscale. The IA and PM scales have demonstrated acceptable to high internal consistency across the studies. 3,4,14,18-20,22,25-27,29-32

The Portuguese version of the IPAS was first translated by two independent researchers. Both translations were compared, and differences analyzed by a senior researcher. Based on these first versions, a debriefing interview was conducted to assess the clarity of the items and face validity of the scale. Following the pilot study, a refined version was developed in a consensus meeting. An independent bilingual translator (with an academic background in Psychology) back-translated the scale to English. Finally, the back-translation and the Portuguese version of the scale were sent back to the original author, who validated and approved the Portuguese version of the IPAS.

Data collection in community samples was conducted both online and in person. The scale was administered in groups for prisoners. 
Psychometric properties of the IPAS - Cruz et al.

Table 1 - Items included on the impulsive aggression (IA) and premeditated aggression (PM) subscales (saturation values in parenthesis)

\begin{tabular}{|c|c|c|c|c|c|c|c|c|c|c|c|c|}
\hline & $\begin{array}{c}\text { Stanford } \\
\text { (unpublished } \\
\text { manual) }\end{array}$ & Stanford ${ }^{3 a *}$ & Kockler ${ }^{4 b} *$ & Mathias $^{14 c *}$ & Haden ${ }^{20 \mathrm{~d} *}$ & Chen $^{15 \mathrm{~d} *}$ & Kuyck $^{19 e^{+}}$ & Rodríguez ${ }^{28 d, f *}$ & Romans $^{1895}$ & Cruz $* \pi$ & Cruz $^{\mathrm{e} * \pi}$ & Azevedo $^{17 \mathrm{e}+\|}$ \\
\hline \multicolumn{13}{|l|}{ IA factor } \\
\hline & 3 & $3(0.57)$ & $3(0.68)$ & & $3(0.58)$ & & 3 & & $3(0.70)$ & $3(0.66)$ & $3(0.74)$ & \\
\hline & 4 & & $4(0.53)$ & & $4(0.57)$ & $4(0.53)$ & 4 & $4(0.87)$ & $4(0.63)$ & $4(0.59)$ & $4(0.59)$ & $4(0.73)$ \\
\hline & & $5(-0.67)$ & & & & & & & & & & \\
\hline & & & & & & & & & $6(0.48)$ & & & \\
\hline & 7 & $7(0.43)$ & $7(0.46)$ & $7(0.50)$ & & & 7 & & $7(0.48)$ & & & $7(0.50)$ \\
\hline & & $8(-0.50)$ & & & & & & & & & & \\
\hline & 9 & $9(0.68)$ & $9(0.61)$ & $9(0.62)$ & $9(0.67)$ & & 9 & $9(0.53)$ & $9(0.68)$ & $9(0.75)$ & $9(0.72)$ & $9(0.80)$ \\
\hline & & & & $11(0.49)$ & & & & & & & & \\
\hline & 13 & & $13(0.46)$ & $13(0.57)$ & $13(0.55)$ & $13(0.47)$ & 13 & & $13(0.68)$ & $13(0.66)$ & $13(0.70)$ & $13(0.72)$ \\
\hline & & & & & $14(0.71)$ & & & & & & & \\
\hline & 15 & & $15(0.59)$ & $15(0.67)$ & $15(0.67)$ & $15(0.58)$ & 15 & $15(0.82)$ & $15(0.51)$ & $15(0.54)$ & $15(0.44)$ & $15(0.72)$ \\
\hline & & & & $16(0.43)$ & & & & & & & & \\
\hline & & & & & & & 17 & & & & $17(0.50)$ & \\
\hline & & & & & $18(0.53)$ & & 18 & & & & & \\
\hline & & & & $19(0.50)$ & & & 19 & $19(0.51)$ & & & $19(0.43)$ & \\
\hline & 21 & & $21(0.56)$ & & & & 21 & & & & $21(0.50)$ & \\
\hline & & & $22(0.65)$ & $22(0.59)$ & & $22(0.64)$ & 22 & $22(0.58)$ & $22(0.66)$ & $22(0.66)$ & $22(0.60)$ & $22(0.79)$ \\
\hline & & & & & & $23(0.49)$ & 23 & & & & & \\
\hline & 24 & $24(0.54)$ & $24(0.60)$ & $24(0.44)$ & & $24(0.43)$ & 24 & $24(0.53)$ & $24(0.64)$ & $24(0.70)$ & $24(0.64)$ & $24(0.72)$ \\
\hline & & & & & & & 25 & $25(0.57)$ & $25(0.50)$ & & & \\
\hline & 26 & $26(0.77)$ & $26(0.55)$ & $26(0.70)$ & $26(0.65)$ & $26(0.67)$ & 26 & $26(0.74)$ & $26(0.76)$ & $26(0.74)$ & $26(0.75)$ & $26(0.66)$ \\
\hline & 27 & & $27(0.66)$ & $27(0.70)$ & $27(0.51)$ & $27(0.63)$ & 27 & $27(0.60)$ & $27(0.46)$ & $27(0.61)$ & $27(0.55)$ & $27(0.66)$ \\
\hline & & & & $28(0.44)$ & & & & & & & & \\
\hline & & & $30(0.68)$ & $30(0.50)$ & & & 30 & & & $30(0.51)$ & & $30(0.63)$ \\
\hline Eigenvalues & ND & ND & 3.94 & 5.53 & ND & ND & ND & ND & 6.99 & 6.69 & 8.19 & 7.19 \\
\hline Variance (\%) & ND & 14.0 & 13 & 18.5 & 9 & 11.9 & ND & 22.5 & 23.30 & 25.7 & 27.3 & 34.3 \\
\hline $\begin{array}{l}\text { Cronbach's } \\
\text { alpha }\end{array}$ & ND & 0.77 & 0.81 & 0.82 & 0.77 & 0.67 & 0.93 & 0.84 & 0.85 & 0.86 & 0.86 & 0.89 \\
\hline \multicolumn{13}{|l|}{ PM factor } \\
\hline & 1 & & $1(0.54)$ & & $1(0.51)$ & & 1 & & $1(0.48)$ & & $1(0.48)$ & $1(0.64)$ \\
\hline & 2 & $2(0.56)$ & $2(0.63)$ & & $2(0.70)$ & & 2 & & $2(0.43)$ & $2(0.53)$ & $2(0.53)$ & $2(0.70)$ \\
\hline & & & $5(0.45)$ & & & & 5 & & & $5(0.54)$ & $5(0.65)$ & \\
\hline & 6 & $6(-0.50)$ & $6(0.72)$ & & $6(0.72)$ & $6(0.56)$ & 6 & $6(0.65)$ & & $6(0.65)$ & $6(0.69)$ & $6(0.58)$ \\
\hline & & & $8(0.46)$ & & & & 8 & & $8(0.43)$ & $8(0.52)$ & & \\
\hline & 10 & & $10(0.54)$ & $10(0.41)$ & $10(0.52)$ & & 10 & & & $10(0.52)$ & $10(0.64)$ & $10(0.63)$ \\
\hline & & $11(0.43)$ & & & & $11(0.44)$ & 11 & & & $11(0.41)$ & & \\
\hline & 12 & $12(0.68)$ & $12(0.62)$ & $12(0.68)$ & $12(0.68)$ & $12(0.62)$ & 12 & $12(0.86)$ & $12(0.60)$ & $12(0.62)$ & $12(0.48)$ & $12(0.80)$ \\
\hline & & & & & & & & $13(0.53)$ & & & & \\
\hline & 14 & $14(0.75)$ & $14(0.66)$ & $14(0.61)$ & & $14(0.42)$ & 14 & $14(0.62)$ & $14(0.67)$ & $14(0.65)$ & & $14(0.65)$ \\
\hline & & $16(0.66)$ & $16(0.60)$ & & & $16(0.62)$ & 16 & $16(0.80)$ & $16(0.63)$ & & $16(0.78)$ & $16(0.72)$ \\
\hline & & $17(0.46)$ & & & & & & $17(0.60)$ & & & & \\
\hline & & & & & & & & & $19(0.43)$ & & & \\
\hline & 20 & $20(0.60)$ & $20(0.59)$ & $20(0.59)$ & & $20(0.44)$ & 20 & $20(0.68)$ & $20(0.49)$ & $20(0.44)$ & $20(0.46)$ & $20(0.75)$ \\
\hline & & & & & & $21(0.48)$ & & $21(0.51)$ & & & & \\
\hline & & & $23(0.63)$ & $23(0.68)$ & & & & $23(0.42)$ & & $23(0.60)$ & $23(0.55)$ & $23(0.55)$ \\
\hline & & & & $25(0.63)$ & & & & & & & $25(0.61)$ & \\
\hline & & & $28(0.66)$ & & $28(0.46)$ & $28(0.47)$ & 28 & $28(0.77)$ & $28(0.65)$ & $28(0.52)$ & $28(0.63)$ & $28(0.75)$ \\
\hline & 29 & $29(0.68)$ & $29(0.66)$ & $29(0.76)$ & $29(0.68)$ & $29(0.68)$ & 29 & $29(0.91)$ & $29(0.77)$ & $29(0.69)$ & $29(0.62)$ & $29(0.64)$ \\
\hline & & $30(0.43)$ & & & & $30(0.41)$ & & & & & & \\
\hline Eigenvalues & ND & ND & 6.14 & 3.33 & ND & ND & ND & ND & 3.03 & 3.01 & 2.87 & 3.29 \\
\hline Variance (\%) & ND & 16.6 & 20 & 15.6 & 24 & 12.9 & ND & 28.5 & 10.1 & 11.6 & 9.6 & 15.7 \\
\hline $\begin{array}{l}\text { Cronbach's } \\
\text { alpha }\end{array}$ & ND & 0.82 & 0.72 & 0.78 & 0.81 & 0.70 & 0.90 & 0.90 & 0.76 & 0.81 & 0.86 & 0.88 \\
\hline
\end{tabular}

Items with loadings $>0.40$ were included in the Portuguese samples of the present study.

ND = no data.

a Physically aggressive men; ${ }^{b}$ forensic sample; ${ }^{c}$ adolescents with conduct disorder; ${ }^{d}$ students; e prisoners; ${ }^{\mathrm{f}}$ adults from the community; ${ }^{g}$ psychiatric patients.

* Principal component analysis/varimax; ${ }^{+}$Confirmatory factor analysis; ${ }^{\ddagger}$ Principal component analysis/promax; ${ }^{\S}$ Principal component analysis/equamax; " Principal component analysis.

" Data related to the present study. 


\section{Results}

Cronbach alpha values for IA items was 0.86 for both samples. As for PM items, the alpha value was 0.81 for the community sample and 0.86 for the prisoner sample. The IA and PM scales were significantly intercorrelated in both samples (community: $r=0.34$, $p<0.05$; prisoners: $r=0.48, p<0.001$ ). In the community sample, IA ranged from 10 to 50 points $(M=27.2 ; S D=7.59)$, which are the minimum and maximum possible values, and PM ranged from 12 to 52 points $(M=30.6 ; S D=7.64)$. As for the $P M$ scale, values could range between a minimum of 12 points and a maximum of 60 points. Still in the community sample, $55.6 \%$ of the participants were classified as predominantly impulsive (dimensional and categorical scoring analysis by gender are presented in Table 2). Similar results were obtained for the forensic sample: the IA scale ranged from 12 to 60 points $(M=35.6$; SD 9.76), and the PM ranged from 12 to 60 points ( $M=$ $30.9 ; S D=9.42)$. In the forensic sample, $74.2 \%$ of the participants were considered predominantly impulsive ( $n=69$ ), against $25.8 \%$ considered predominantly premeditated ( $n=24)$.

To replicate the original study on the scale ${ }^{3}$ we performed an exploratory principal component analysis with normalized varimax rotation to determine the structure of the Portuguese version of the IPAS in the community sample. Two factors were extracted with a cut-off of 0.40 for item inclusion, and a minimum threshold of 2.0 (Eigenvalues) for factor retention: (a) IA, accounting for $25.7 \%$ of the total variance; and (b) PM, explaining $11.6 \%$ of the total variance. Items were excluded if they: (a) presented loadings $<0.40$ ("I usually can't recall the details of the incidents well"; "I knew most of the persons involved in the incidents"; "I was concerned for my personal safety during the acts"); or (b) loaded $>0.40$ on both components ("My aggressive outbursts were usually directed at a specific person").

Similar results were found in the forensic sample: (a) an IA factor accounting for $27.3 \%$ of the total variance; and (b) a PM factor explaining $9.6 \%$ of the total variance. Six items were dropped due to (a) loadings $<0.40$ ("I usually can't recall the details of the incidents well"; "I understood the consequences of the acts before I acted"; "I felt pressure from others to commit the acts"; "I think the other person deserved what happened to them during some of the incidents"; "I knew most of the persons involved in the incidents"); or (b) item loadings on both factors ("Anything could have set me off prior to the incidents"). Table 1 shows a summary of the factorial structure of the scale across different studies.

\section{Discussion}

Despite the heterogeneity of aggressive behavior, impulsivity and premeditation have long been accepted as the two primary forms of aggression. There is evidence that the psychometric structure of the Portuguese community and forensic samples here assessed replicate previous findings in the literature, which makes data obtained from this Portuguese version acceptable. Our results support the notion that impulsivity and premeditation can be effectively measured across different samples, and the twofactor structure solution provides the best theoretical and statistical differentiation of aggressive behavior tendencies. Both community and incarcerated participants reported higher levels of impulsive than premeditated aggression.

This study presents some limitations. First, the sample of offenders included male participants only and the severity of the crimes was not controlled. Second, we have no means to check whether the participants under- or over-reported aggressive acts.

Individual classification into different aggressiveness features in the community and in the criminal justice system may provide evidence for a better management of offenders and a more efficient definition of treatment strategies, adapted to the individuals' needs and responsivity. Additionally, future studies should extend

Table 2 - Mean values (SD) of IA and PM subscales and frequency distribution of predominantly aggressive category according to gender

\begin{tabular}{lcc}
\hline & IA score, mean (SD) & PM, mean (SD) \\
\hline Male $(\mathrm{n}=424)$ & $26.9(7.34)$ & $31.5(7.84)$ \\
Female $(\mathrm{n}=534)$ & $27.4(7.78)$ & $29.9(7.40)$ \\
\hline & Predominantly IA, \% & Predominantly PM, \% \\
\hline Male $(\mathrm{n}=379)$ & 49.6 & 50.4 \\
Female $(\mathrm{n}=467)$ & 60.4 & 39.6 \\
\hline
\end{tabular}

IA = impulsive aggression; PM = premeditated aggression; SD = standard deviation. 
these findings to other samples (e.g., clinical samples, adolescents with conduct disorder) and test the consistency of the results by measuring the invariance of the scale constructs in the Portuguese population.

\section{Acknowledgments}

This work was supported by Fundação para a Ciência e a Tecnologia (grant SFRH/BD/76062/2011), awarded to the first author. The study was also supported by grant SFRH/BPD/108602/2015 from Fundação para a Ciência e a Tecnologia awarded to Andreia Castro Rodrigues.

\section{Disclosure}

No conflicts of interest declared concerning the publication of this article.

\section{References}

1. Parrott DJ, Giancola PR. Addressing "The criterion problem" in the assessment of aggressive behavior: Development of a new taxonomic system. Aggress Violent Behav. 2007;12:280-99.

2. Volavka J. The neurobiology of violence: an update. J Neuropsychiatry Clin Neurosci. 1999;11:307-14.

3. Stanford MS, Houston RJ, Mathias CW, Villemarette-Pittman NR, Helfritz LE, Conklin SM. Characterizing aggressive behavior. Assessment. 2003;10:183-90.

4. Kockler TR, Stanford MS, Nelson CE, Meloy JR, Sanford K. Characterizing aggressive behavior in a forensic population. Am J Orthopsychiatry. 2006;76:80-5.

5. Moeller FG, Barratt ES, Dougherty DM, Schmitz JM, Swann AC. Psychiatric aspects of impulsivity. Am J Psychiatry. 2001;158:1783-93.

6. Villemarette-Pittman NR, Stanford MS, Greve KW. Language and executive function in self-reported impulsive aggression. Pers Individ Dif. 2003;34:1533-44.

7. Broomhall L. Acquired sociopathy: A neuropsychological study of executive dysfunction in violent offenders. Psychiatry Psychol Law. 2005;12:367-87.

8. Raine A, Meloy JR, Bihrle S, Stoddard J, LaCasse L, Buchsbaum MS. Reduced prefrontal and increased subcortical brain functioning assessed using positron emission tomography in predatory and affective murderers. Behav Sci Law. 1998;16:319-32.

9. Meloy JR. Empirical basis and forensic application of affective and predatory violence. Aust N Z J Psychiatry. 2006;40:539-47.

10. Brower $\mathrm{MC}$, Price $\mathrm{BH}$. Neuropsychiatry of frontal lobe dysfunction in violent and criminal behaviour: A critical review. J Neurol Neurosurg Psychiatry. 2001;71:720-6.

11. Cooke D, Michie C, De Brito S, Hodgins S, Sparkes L. Measuring life-long patterns of instrumental aggression: a methodological note. Psychol Crime Law. 2011;17:37-41.

12. Vitaro F, Brendgen M, Tremblay RE. Reactively and proactively aggressive children: Antecedent and subsequent characteristics. J Child Psychol Psychiatry Allied Discip. 2002;43:495-505.

13. Cornell DG. Coding guide for violent incidents: Instrumental versus hostile/reactive aggression [Internet]. 1996. https:// curry.virginia.edu/uploads/resourceLibrary/Violence_Coding_
Guide_for_Instrumental_and_Hostile-Reactive_Incidents_10-513.pdf

14. Mathias CW, Stanford MS, Marsh DM, Frick PJ, Moeller FG, Swann $\mathrm{AC}$, et al. Characterizing aggressive behavior with the Impulsive/ Premeditated Aggression Scale among adolescents with conduct disorder. Psychiatry Res. 2007;151:231-42.

15. Chen FR, Yang $Y$, Qian M. Chinese version of Impulsive/ Premeditated Aggression Scale: Validation and its psychometric properties. J Aggress Maltreat Trauma. 2013;22:175-91.

16. Cruz AR, Barbosa F. [Contribution to the characterization of aggressive behavior - An exploratory study based on the Impulsive-Premeditated Aggression Scale]. Psiquiatr Psicol Just. 2010;3:101-9. http://www.spppj.com/uploads/n 3.pdf

17. Azevedo JC, Pais-Ribeiro JL, Coelho R, Figueiredo-Braga $M$. Validation of the Portuguese version of Impulsive-Premeditated Aggression Scale in an inmate population. Front Psychiatry. 2018;9:1-8.

18. Romans L, Fresán A, Sentíes H, Sarmiento E, Berlanga C, Robles-García $\mathrm{R}$, et al. Validation of the Impulsive/Premeditated Aggression Scale in Mexican psychiatric patients. Nord J Psychiatry. 2015;69:397-402.

19. Kuyck WGE, de Beurs $E$, Barendregt $M$, van den Brink W. Psychometric evaluation of the Dutch version of the Impulsive/ Premeditated Aggression Scale (IPAS) in male and female prisoners. Int J Forensic Ment Health. 2013;12:172-9.

20. Haden SC, Scarpa A, Stanford MS. Validation of the Impulsive/ Premeditated Aggression Scale in college students. J Aggress Maltreatment Trauma. 2008;17:352-73.

21. Ostrov JM, Houston RJ. The utility of forms and functions of aggression in emerging adulthood: Association with personality disorder symptomatology. J Youth Adolesc. 2008;37:1147-58.

22. Swing $\mathrm{EL}$, Anderson CA. The role of attention problems and impulsiveness in media violence effects on aggression. Aggress Behav. 2014;40:197-203.

23. Derkzen DM. Impulsivity, social problem solving and alcohol dependency as contributors to aggression in a sample of provincially incarcerated offenders [dissertation]. Saskatchewan: Saskatoon; 2007.

24. Steadham JA, Rogers R. Predictors of reactive and instrumental aggression in jail detainees: An initial examination. J Forensic Psychol Pract. 2013;13:411-28.

25. Swogger MT, Walsh Z, Houston RJ, Cashman-Brown S, Conner KR. Psychopathy and Axis I psychiatric disorders among crimina offenders: Relationships to impulsive and proactive aggression. Aggress Behav. 2010;36:45-53.

26. Conner KR, Houston RJ, Sworts LM, Meldrum S. Reliability of the Impulsive-Premeditated Aggression Scale (IPAS) in treated opiate-dependent individuals. Addict Behav. 2007;32:655-9.

27. Long K, Felton JW, Lilienfeld SO, Lejuez CW. The role of emotion regulation in the relations between psychopathy factors and impulsive and premeditated aggression. Personal Disord Theory Res Treat. 2014;5:390-6.

28. Rodríguez LL. Validación psicométrica de la versión española de la Escala de Agresión Impulsiva y Premeditada (IPAS). Madrid: Universidad Complutense de Madrid, Faculdad de Psicología; 2015.

29. Teten AL, Miller LA, Bailey SD, Dunn NJ, Kent TA. Empathic deficits and alexithymia in trauma-related impulsive aggression. Behav Sci Law. 2008;26:823-32.

30. Conner KR, Swogger MT, Houston RJ. A test of the reactive aggression-suicidal behavior hypothesis: is there a case for proactive aggression? J Abnorm Psychol. 2009;118:235-40.

31. Teten AL, Miller LA, Stanford MS, Petersen NJ, Bailey SD, Collins $\mathrm{RL}$, et al. Characterizing aggression and its association to anger and hostility among male veterans with post-traumatic stress disorder. Mil Med. 2010;175:405-10.

32. Swogger MT, Walsh Z, Maisto SA, Conner KR. Reactive and proactive aggression and suicide attempts among criminal offenders. Crim Justice Behav. 2014;41:337-44.

\section{Correspondence:}

Ana Rita Cruz

E-mail: anaritapcruz@gmail.com 